\title{
The consistency of laboratory jet erosion tests performed on undisturbed samples
}

\author{
J. L. Wibowo \& B. A. Robbins \\ U.S. Army Corps of Engineers, Engineer Research and Development Center \\ 3909 Halls Ferry Road, Vicksburg, MS 39180, USA
}

\begin{abstract}
The U.S. Army Engineer Research and Development Center performed 75 laboratory Jet Erosion Tests (JETs) on undisturbed samples collected from the riverbank along the Lower American River (LAR) near the city of Sacramento, California, to identify the erosion resistance of soil along the riverbanks and riverbed of the LAR through the erosion parameters of erodibility coefficient, $K_{d}$, and critical stress, $\tau_{c}$. Thirty-nine of the samples were Shelby tube samples and the other forty-two were 4-in.-diameter Plexiglas tube samples. The soil type varied from weak sandy silt to stiff silt with the JET results varying from Very Erodible (VE) to Very Resistant (VR). For many of the samples, the variations in results were due to changes in the quality of the undisturbed samples; however, the variations may also be caused by the changes in the soil type from silt/sand to clay in some of the tested samples and natural variability of the soils. The method of sampling tube and the process of cutting the tube may also add to the variability in test results. To use the erosion parameters for specific soil types outside of the samples tested, the erosion parameters were related to index properties of the soil: particle diameter, percent clay content, and Plasticity Index. Erosion parameters were found to be most significant correlated to the particle diameter.
\end{abstract}

\section{INTRODUCTION}

The JET Erosion Test (JET) was initiated by the United States Department of Agriculture (USDA) in 1990 (Hanson, 1990) as a means of characterizing the in situ erodibility of earthen channel materials. Since then, the procedure has been modified to incorporate objective, analytical procedures for interpreting the test results (Hanson \& Cook, 2004) such that quantitative descriptions of soil erosion characteristics can be systematically obtained. This has resulted in the JET results being used for applications such as numerical modeling of lateral stream bank erosion, earthen spillway erosion, and embankment breach evolution (Simon et al., 2011, USDA 1977, Temple et al. 2005, Hanson et al. 2005) While the primary advantage of the JET over alternative erosion test is the fact that it can be conducted in situ, situations may rise in which it is desirable to conduct erosion tests on undisturbed samples. This paper presents one such case in which erosion properties of soil were desired at depth to evaluate the potential for lateral erosion of the Lower American River (LAR) near Sacramento, California. An overview of the study area, testing program and test results are provided. Since erosion parameters are not always available, the erosion parameters are related to basic properties of soils: median particle diameters $\mathrm{D}_{50}$, percentage of fine content (pass Sieve \#200), and Plasticity Index (PI).

\section{BACKGROUND}

The American River flows southwestward from the northern Sierra Nevada mountain range to its mouth at the confluence with the Sacramento River in Sacramento, California. The LAR is the portion of the American River below Folsom Dam (Figure 1). The evolution of the LAR over the last two centuries has been dominated by anthropological influences. As noted by James (1997), two major perturbations led to a cycle of aggradation and degradation along the LAR: nineteenth-century hydraulic gold-mining sediment production and construction of dams and levees. Hydraulic mining began in 1853 and continued until 1884 (Gilbert, 1917). This mining activity led to deposition of sediment that ranged from 1.5 to $9.0 \mathrm{~m}$ in depth along the LAR (James, 1997). After Folsom and Nimbus dams were constructed in the $1950 \mathrm{~s}$, the upstream sediment supply of the LAR drastically decreased leading to continuous degradation of the channel (Fairman, 2007). Furthermore, the river degradation has decreased nearly to an equilibrium condition. This is primarily due to the channel invert elevation 
reaching through the recent mining deposits into the more erosion resistant, Pleistocene deposits. Because this equilibrium condition has been reached, future increases in flow will likely cause the river to respond through channel widening in the form of bank erosion. This behavior has already been exhibited during the 1986 floods when a peak release of $134,000 \mathrm{cfs}$ caused significant erosion within the system currently designed for $115,000 \mathrm{cfs}$ (Ayres Associates, 2010). In 2004, the LAR and adjacent levees were reviewed for a potential discharge of 145,000 cfs; and, currently, the system is under review for a further increase in the release from Folsom Dam to 160,000 cfs. During a 2010 study of the system, Ayres Associates identified key areas in which erosion of the river banks may be of concern (Ayres Associates, 2010). As a result, further investigations are being conducted in an attempt to map 'geologic hard points' that may resist erosion. This paper documents the JETs that were conducted on samples obtained as part of this ongoing investigation.

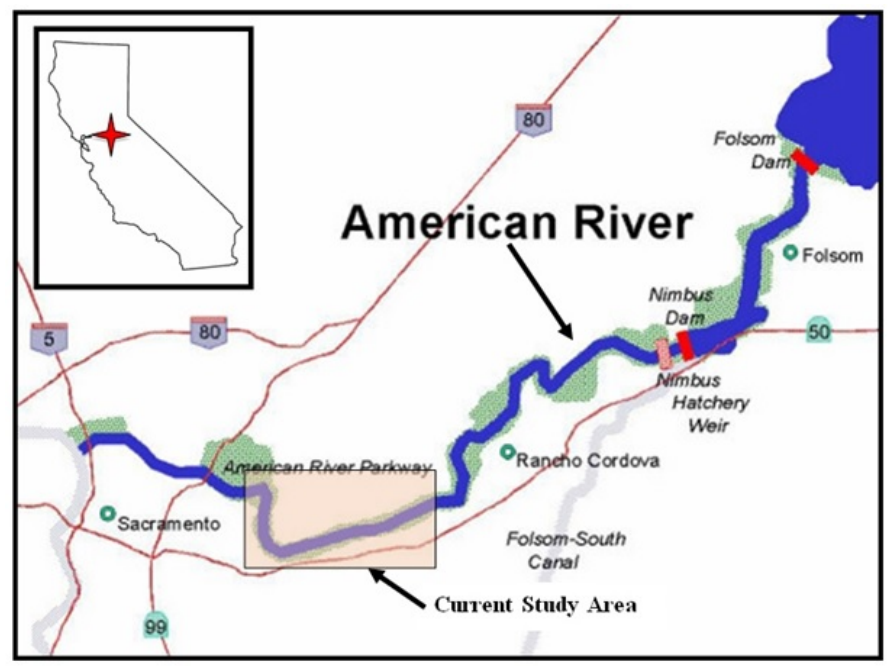

Figure 1. Lower American River Watershed (USFS, 2014).

\section{STUDY AREA}

The current study area extends from River Mile 5 near Glenn Hall Park to River Mile 10 past Watt Avenue Bridge as shown in Figures 1 and 2. Thirtyeight, four-inch-diameter undisturbed core samples were obtained from two phases of drilling operations. The first phase of sampling used 4-inchdiameter steel Shelby tubes, and the second phase of sampling used 4-inch diameter polycarbonate core tubes. All sampling was conducted using a Pitcher Tube sampler. Additionally, one undisturbed block sample was obtained for a JET.

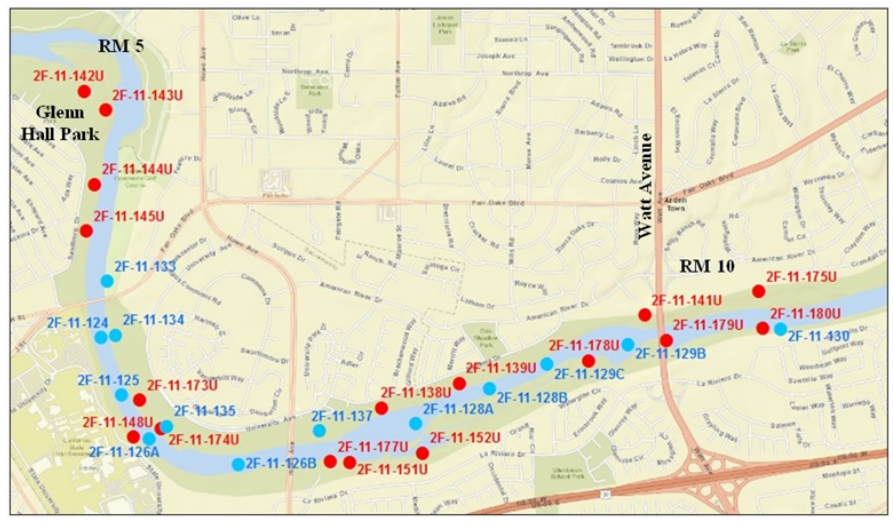

Figure 2. Boring locations for JET samples for (Blue) Phase I samples and (Red) Phase II samples.

\section{JET EROSION TEST}

The JET was initially developed by Greg Hanson of the U.S. Department of Agriculture, Agriculture Research Service as a means of predicting the erodibility of cohesive soils in stream beds (Hanson, 1991). The original test method consisted of a highvelocity, submerged jet of water impinging on the soil surface. The change in maximum scour depth caused by the impinging jet was recorded versus time and used to find a soil-dependent "jet index." The test procedure is documented in ASTM Standard D5852-07 (ASTM, 2007) and uses an empirical relationship to determine the "jet index," which is then correlated to the erodibility coefficient. In an attempt to remove this empiricism, Hanson \& Cook (1997, 2011) developed analytical procedures for directly calculating soil erodibility and critical stress based on the diffusion principles of a submerged, circular jet building on the previous work of Stein \& Nett (1997). This modified analytical procedure (not yet an ASTM Standard) was used to process test data and is discussed briefly below. For a full discussion and derivation of this procedure, see Hanson \& Cook $(1997,2004)$.

The JET is based on a commonly used relationship (Hanson, 1991) for characterizing erodibility of soils given as

$\varepsilon=k_{d}\left(\tau_{e} \tau_{c}\right)$

where $\varepsilon=$ the erosion rate of soil in volume per unit time per unit area $\left(\mathrm{m}^{3} \mathrm{~s}^{-1} \mathrm{~m}^{-2}\right) ; \mathrm{k}_{\mathrm{d}}=$ the erodibility or detachment coefficient $\left(\mathrm{m}^{3} \mathrm{~N}^{-1} \mathrm{~s}^{-1)} ; \tau_{\mathrm{e}}=\right.$ the local effective stress $(\mathrm{Pa}) ; \tau_{\mathrm{c}}=$ the critical stress $(\mathrm{Pa})$.

Equation 1 represents the physical process of erosion and describes the rate of erosion of a geologic material is proportional to the difference in effective stress and critical stress. The purpose of the 
JET is to solve for the erodibility coefficient and critical stress such that erosion can be predicted for any given hydraulic loading. A schematic diagram of the jet erosion process is shown in Figure 3. Under this configuration, Hanson \& Cook (1997) showed that the critical stress of circular flow may be defined using Equations 2 through 5

$\tau_{c}=\tau_{0}\left(\frac{J_{p}}{J_{e}}\right)^{2}$

$J_{p}=C_{d} d_{0}$

$\tau_{0}=C_{f} \rho U_{0}^{2}$

$U_{0}=\sqrt{2 g h}$

where $\tau_{\mathrm{c}}=$ critical shear stress $(\mathrm{Pa}) ; \tau_{0}=$ the maximum stress within potential core $(\mathrm{Pa}) ; \mathrm{J}_{\mathrm{p}}=$ the potential core length $(\mathrm{m}) ; \mathrm{J}_{\mathrm{e}}=$ the equilibrium depth $(\mathrm{m}) ; \mathrm{C}_{\mathrm{d}}=$ diffusion constant $=6.3 ; \mathrm{d}_{0}=$ nozzle diameter $(\mathrm{m}) ; \mathrm{C}_{\mathrm{f}}=$ friction coefficient; $\rho=$ fluid density $\left(\mathrm{kg} / \mathrm{m}^{3}\right) ; \mathrm{U}_{0}=$ velocity at the jet nozzle $(\mathrm{m} / \mathrm{s})$; $\mathrm{g}=\operatorname{gravity}\left(\mathrm{m} / \mathrm{s}^{2}\right) ; \mathrm{h}=$ differential head $(\mathrm{m})$.

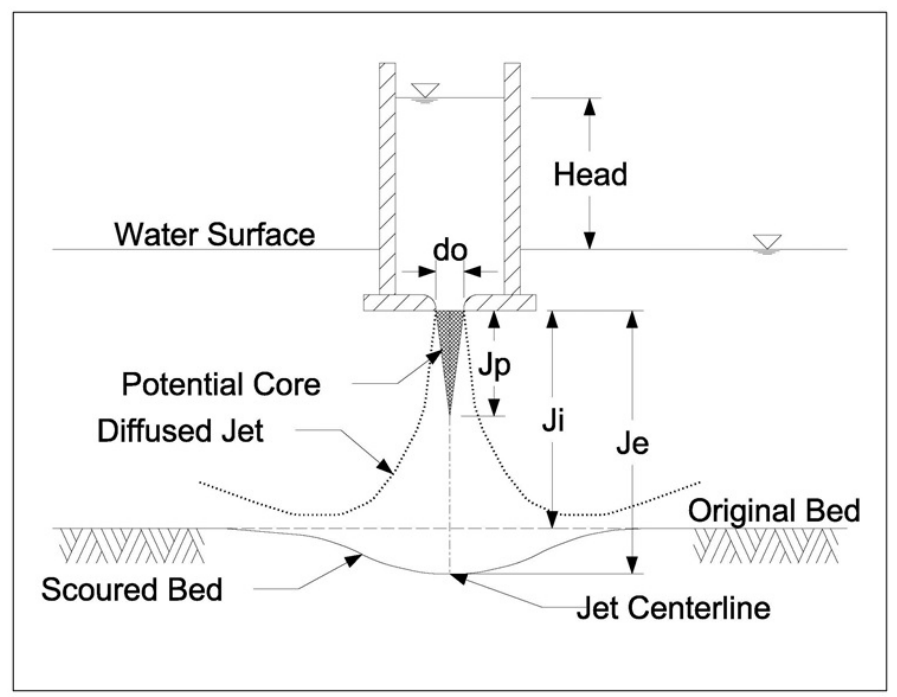

Figure 3. Schematic diagram of the jet erosion process (After Hanson \& Cook (1997).

The critical stress refers to the stress exerted by the jet, once the equilibrium scour depth has been reached. Because the length of time needed to reach equilibrium can be long, Hanson \& Cook used the expression proposed by Bleisdell et al. (1981) that assumes the scour rate conforms to a logarithmic hyperbolic function. The equilibrium depth is found by fitting the field data for Bleisdell's curve (Hanson et al., 2002), and the critical stress can be found using Equation 2. The erodibility coefficient is then determined by curve fitting the actual measurement of scour depth and time to a dimensionless form of
Equation 1. A more detailed discussion of this procedure can be found in Hanson \& Cook (2004).

\section{TESTING PROCEDURE AND SAMPLE PREPARATION}

The test apparatus consisted of a water tank, a water pump, a pressure control manifold, one JET unit, and pressure instrumentation (Figure 4). The design of the test apparatus was based on modifications by the USDA, Agricultural Research Service, National Sedimentation Laboratory at Oxford, MS, of the original device developed by Hanson. The original JET device used a constant head tank to supply pressure, whereas the modified device uses the direct head supplied by the pump. While this may lead to minor fluctuations in pressure during testing, it is more suitable for high-strength, dense geologic materials as it allows for a larger range of pressure head.

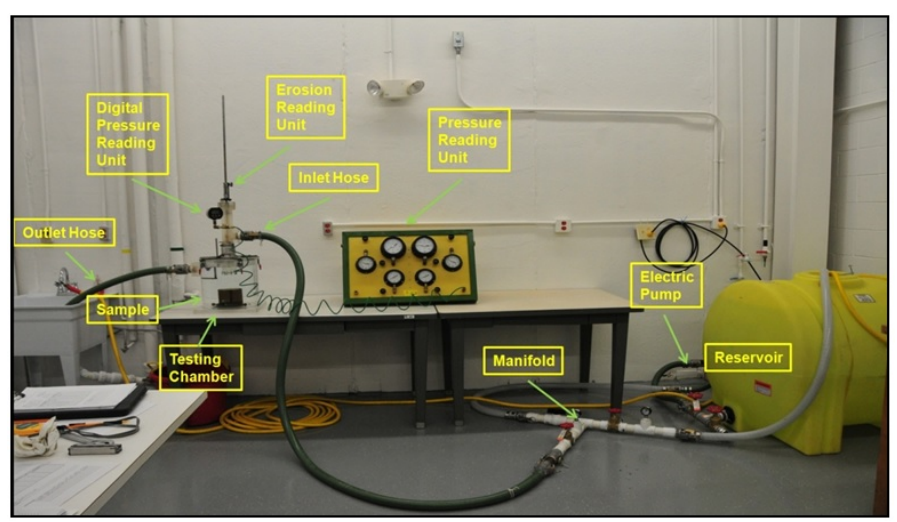

Figure 4. Laboratory JET apparatus at Vicksburg, MS.

The testing device is designed to accept 4-inchdiameter specimens ranging from 4 to 6 inches in height. Therefore, the undisturbed tube samples were cut to the appropriate size for the test apparatus resulting in an additional source of sample disturbance that may affect the test results. In an attempt to minimize sample disturbance, the sample and the sample tube were cut as a whole rather than extruded and trimmed. The method by which the sample was cut depended on the type of sample tube. For steel Shelby tube sample, the tube itself was cut with a 4-wheeled pipe cutter (Figure 5A) to try and avoid significant vibration that may result from a saw. Once the pipe cutter penetrated the steel, a wire sample trimmer was used to cut through the soil sample leaving a smooth, uniform surface. The polycarbonate core tubes were easier to cut, as a grinder could be used to easily remove the plastic along a cutting line (Figure 5B) without causing significant vibration or disturbance. Once the polycarbonate was fully penetrated around the sample, the soil was again cut with a wire sample 
trimmer. In some instances, the soil was to stiff to cut with a wire saw, and a fine-toothed, steel saw had to be used. Samples were cut to be approximately 4 inches in height.

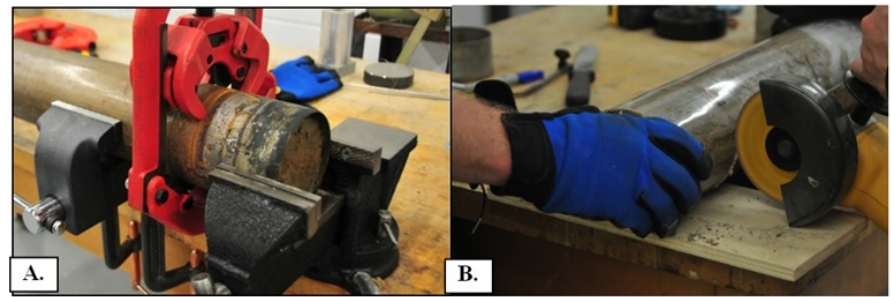

Figure 5. Sample preparation for (A) Steel Shelby tubes and (B) Polycarbonate core tubes.

Once the sample was trimmed, water content samples were taken from the exposed soil face at the cut. The samples were then weighed and photographed prior to mounting inside a clamp at the base of the laboratory JET device. With the sample firmly mounted in the device, an initial reading of the distance from the orifice to the soil surface was taken with the point gage. The point gage consists of a circular probe that travels through the JET orifice such that a point measurement can be made at the center of the sample. The deflector plate was then positioned in front of the jet, and the chamber slowly filled with water. Once the jet was submerged, the test was commenced. The jet was allowed to impact the soil sample for timed intervals with depth readings taken after every interval. The pressure head was initially set at 0.5 psi to ensure erosion did not occur too quickly for highly erodible soils. If no erosion occurred, the pressure was increased incrementally until the maximum operating pressure of 5 psi was reached, at which point the test was terminated if erosion had not yet initiated. If erosion did occur, the operating pressure was held constant; and the depth of erosion was recorded at timed intervals yielding a data record of erosion as a function of time. Figures $6 a-d$ show a new sample before testing, mounted in the testing device, following completion of the test, and the resulting data, respectively.

\section{TEST RESULTS}

In an attempt to assess repeatability, two tests were conducted on all samples whenever possible. This resulted in a total of 75 JETs being conducted on the undisturbed samples as part of this study. Data obtained from the 75 JETs were processed using the analytical procedures previously discussed to obtain a critical stress and erodibility coefficient for each test. The processed data from the tests were classified using the erosion categories proposed by Hanson \& Simon (2001) as shown for four of the tests in Figure 7. As seen in Figure 7, conducting pairs of tests on the samples allowed for disturbance or material changes to be readily assessed through a graphic comparison of the results. The results for sample $143 \mathrm{U}$ are very close together, providing confidence that adequate characterization of the sample erosion characteristics was obtained. The results for sample 142U, however, are quite different indicating that either the material was different or significant disturbance existed on one of the specimens. The complete discussion of the effects of disturbance of soil sampling methods can be found in Robbins \& Wibowo (2015). The 29 selected soil samples are tabulated in Tables 1 and 2 for phase I and the test results for phase II are shown in Tables 3 and 4. The selection was done in regard to the results of laboratory test which have the set of values of critical shear stress, erodibility coefficient, $\mathrm{D}_{50}$, clay content, and Plasticity Index (PI). For that reason the sample with category of very resistant is not presented in the tables.

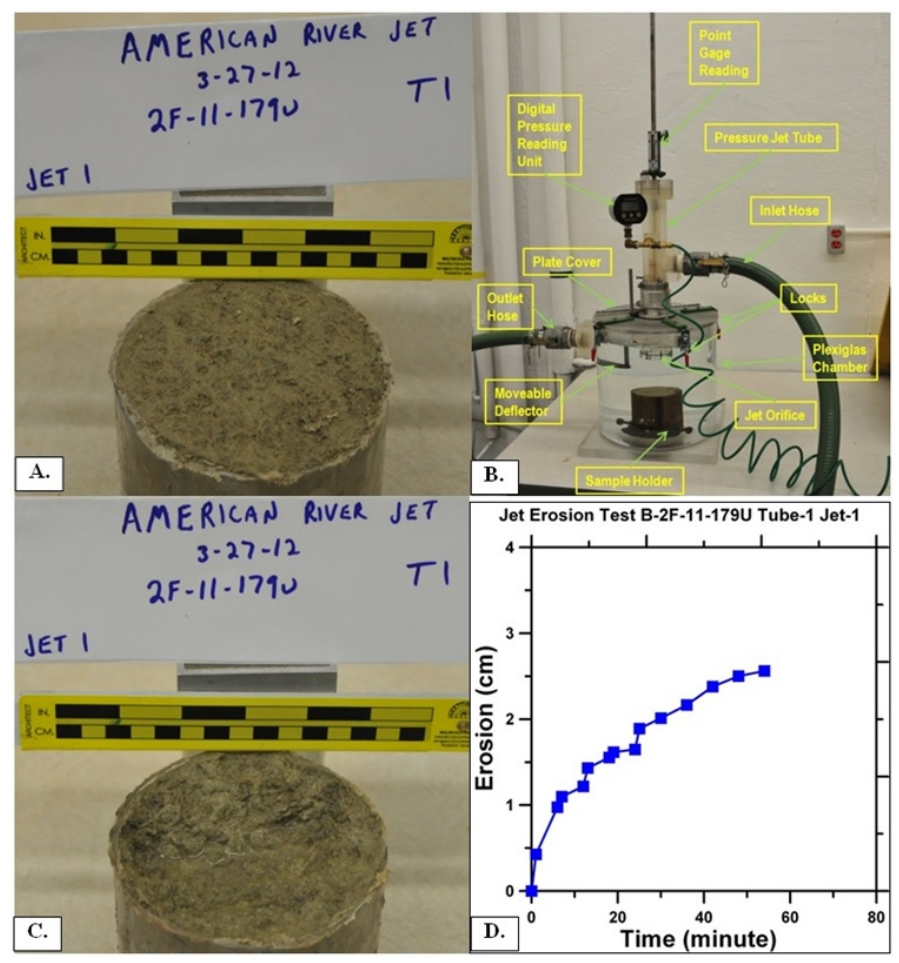

Figure 6. Photo of a sample (A) before a test, (B) mounted in the JET device, (C) following completion of the test, and (D) the resulting data. 


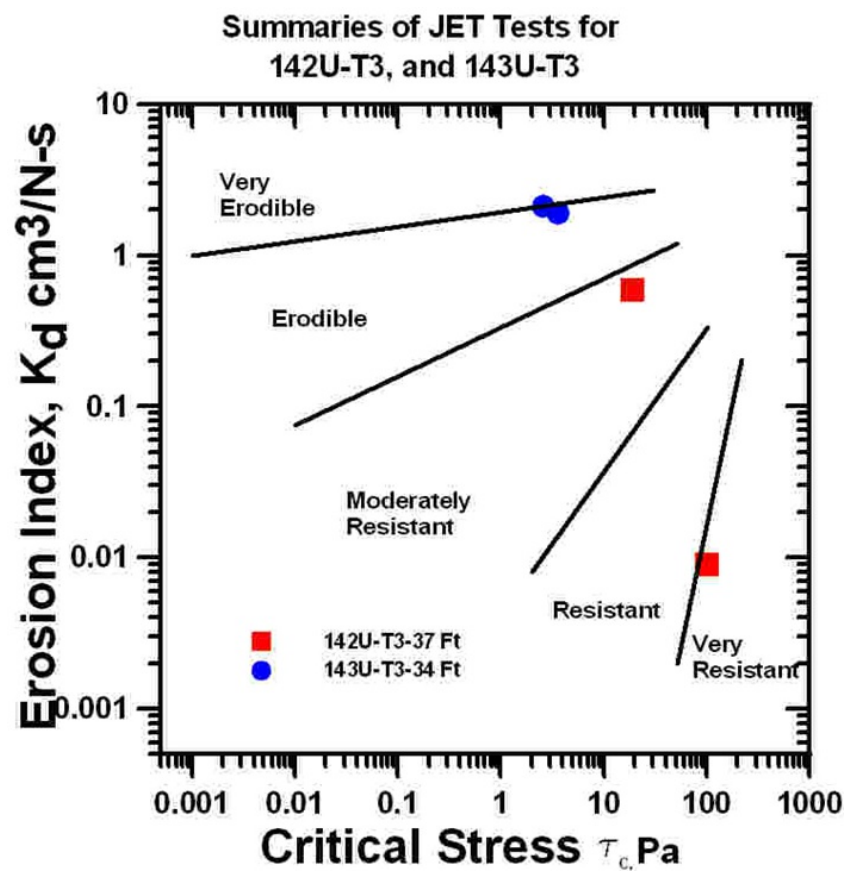

Figure 7. Categorization of sample as Very Erodible (VR), Erodible (E), Moderately Resistant (MR), Resistant (R), or Very Resistant (VR) based on the JET results and criteria set forth by Hanson \& Simon (2001).

Table 1. Phase I Samples.

\begin{tabular}{|c|c|r|c|}
\hline Sample \# & Boring and Test No. & $\begin{array}{c}\text { Depth } \\
(\mathrm{ft})\end{array}$ & $\begin{array}{c}\text { Soil } \\
\text { Type }\end{array}$ \\
\hline 1 & 2F-11-124-Tube-1 Jet \#1 & 13.1 & ML \\
2 & 2F-11-125-Tube-2 Jet \#1 & 11.4 & ML \\
3 & 2F-11-126A-Tube-2 Jet \#2 & 19.0 & ML \\
4 & 2F-11-126B-Tube-2 Jet \#1 & 7.8 & ML \\
5 & 2F-11-126B-Tube-3 Jet \#1 & 21.4 & SM \\
6 & 2F-11-128A-Tube-1 Jet \#1 & 18.1 & ML \\
7 & 2F-11-128A-Tube-3 Jet \#2 & 23.8 & ML \\
8 & 2F-11-128B-Tube-1 Jet \#1 & 11.8 & ML \\
9 & 2F-11-128B-Tube-3 Jet \#1 & 23.1 & SP \\
10 & 2F-11-129C-Tube-1 Jet \#1 & 8.3 & ML \\
11 & 2F-11-133-Tube-1 Jet \#1 & 39.6 & SM \\
12 & 2F-11-134-Tube-2 Jet \#1 & 49.6 & ML \\
13 & 2F-11-137-Tube-1 Jet \#1 & 23.6 & ML \\
14 & 2F-11-137-Tube-4 Jet \#1 & 46.6 & SP-SM \\
\hline
\end{tabular}

Note: $\mathrm{VE}=$ Very Erodible, $\mathrm{E}=$ Erodible, $\mathrm{MR}=$ Moderately

Resistant, $\mathrm{R}=$ Resistant, VR $=$ Very Resistant.

Table 2. Phase I Samples.

\begin{tabular}{|c|c|c|c|}
\hline Sample \# & Boring and Test No. & $\begin{array}{c}\text { Depth } \\
(\mathrm{ft})\end{array}$ & $\begin{array}{c}\text { Soil } \\
\text { Type }\end{array}$ \\
\hline 15 & 2F-11-138U-Tube-1 Jet \#1 & 27.0 & SM \\
16 & 2F-11-138U-Tube-4 Jet \#1 & 50.5 & ML \\
17 & 2F-11-139U-Tube-4 Jet \#1 & 47.7 & ML \\
18 & 2F-11-141U-Tube-1 Jet \#1 & 25.5 & ML \\
19 & 2F-11-142U-Tube-3 Jet \#2 & 36.3 & ML \\
20 & 2F-11-143U-Tube-3 Jet \#1 & 34.7 & ML \\
21 & 2F-11-145U-Tube-2 Jet \#2 & 49.3 & ML \\
22 & 2F-11-148U-Tube-3 Jet \#2 & 37.3 & ML \\
23 & 2F-11-151U-Tube-2 Jet \#1 & 26.0 & SM \\
24 & 2F-11-174U-Tube-2 Jet \#2 & 38.3 & ML \\
25 & 2F-11-175U-Tube-2 Jet \#1 & 47.7 & SM \\
26 & 2F-11-178U-Tube-1 Jet \#1 & 15.7 & ML \\
27 & 2F-11-179U-Tube-1 Jet \#1 & 14.7 & ML \\
28 & 2F-11-179U-Tube-4 Jet \#2 & 25.6 & ML \\
29 & 2F-11-180U-Tube-2 Jet \#2 & 27.3 & ML \\
\hline
\end{tabular}

Note: $\mathrm{VE}=$ Very Erodible, $\mathrm{E}=$ Erodible, $\mathrm{MR}=$ Moderately Resistant, $\mathrm{R}=$ Resistant, VR $=$ Very Resistant.
Table 3. Phase II JET Results.

\begin{tabular}{|c|c|c|c|c|c|c|c|}
\hline $\begin{array}{c}\text { Sample } \\
\#\end{array}$ & $\begin{array}{c}\text { Soil } \\
\text { Type }\end{array}$ & $\begin{array}{c}\tau_{\mathrm{c}} \\
(\mathrm{Pa})\end{array}$ & $\begin{array}{c}\mathrm{k}_{\mathrm{d}} \\
\left(\mathrm{cm}^{3} / \mathrm{N}^{-\mathrm{s}}\right)\end{array}$ & $\begin{array}{c}\mathrm{D}_{50} \\
(\mathrm{~mm})\end{array}$ & $\begin{array}{c}\text { Fine } \\
\text { Content } \\
(\%)\end{array}$ & PI & Category \\
\hline 1 & ML & 14.603 & 0.594 & 0.0477 & 56.8 & 10 & MR \\
2 & ML & 30.571 & 0.506 & 0.0204 & 94.5 & 13 & MR \\
3 & ML & 28.585 & 0.229 & 0.0515 & 77.7 & NP & MR \\
4 & ML & 0.822 & 0.965 & 0.0388 & 92.0 & 2 & E \\
5 & SM & 1.703 & 179.5 & 0.1082 & 38.3 & NP & VE \\
6 & ML & 12.471 & 1.13 & 0.0431 & 67.0 & 9 & E \\
7 & ML & 16.739 & 0.347 & 0.0214 & 93.3 & 7 & MR \\
8 & ML & 27.118 & 0.231 & 0.0463 & 80.6 & NP & MR \\
9 & SP & 0.005 & 1293.3 & 0.2268 & 4.8 & NP & VE \\
10 & ML & 2.539 & 2.937 & 0.0727 & 51.3 & NP & VE \\
11 & SM & 2.419 & 99.99 & 0.0541 & 66.5 & NP & VE \\
12 & ML & 4.127 & 0.783 & 0.0508 & 76.1 & 11 & E \\
13 & ML & 0.787 & 113.9 & 0.0573 & 60.9 & NP & VE \\
14 & SP-SM 2.126 & 437.3 & 0.1345 & 15.0 & NP & VE \\
\hline
\end{tabular}

Note: $\mathrm{VE}=$ Very Erodible, $\mathrm{E}=$ Erodible, $\mathrm{MR}=$ Moderately Resistant, $\mathrm{R}=$ Resistant, $\mathrm{VR}=$ Very Resistant.

Table 4. Phase II JET Results.

\begin{tabular}{|c|c|c|c|c|c|c|c|}
\hline $\begin{array}{c}\text { Sample } \\
\#\end{array}$ & $\begin{array}{c}\text { Soil } \\
\text { Type }\end{array}$ & $\begin{array}{c}\tau_{\mathrm{c}} \\
(\mathrm{Pa})\end{array}$ & $\begin{array}{c}\mathrm{k}_{\mathrm{d}} \\
\left(\mathrm{cm}^{3} / \mathrm{N}^{-\mathrm{s}}\right)\end{array}$ & $\begin{array}{c}\mathrm{D}_{50} \\
(\mathrm{~mm})\end{array}$ & $\begin{array}{c}\text { Fine } \\
\text { Content } \\
(\%)\end{array}$ & PI & Category \\
\hline 15 & $\mathrm{SM}$ & 0.865 & 52.08 & 0.1681 & 25.4 & $\mathrm{NP}$ & $\mathrm{VE}$ \\
16 & $\mathrm{ML}$ & 1.441 & 6.25 & 0.0426 & 85.7 & $\mathrm{NP}$ & $\mathrm{VE}$ \\
17 & $\mathrm{ML}$ & 20.55 & 0.296 & 0.0115 & 96.6 & 13 & $\mathrm{MR}$ \\
18 & $\mathrm{ML}$ & 3.86 & 4.444 & 0.0529 & 65.6 & $\mathrm{NP}$ & $\mathrm{VE}$ \\
19 & $\mathrm{ML}$ & 18.9 & 0.588 & 0.0475 & 75.3 & $\mathrm{NP}$ & $\mathrm{MR}$ \\
20 & $\mathrm{ML}$ & 2.58 & 2.105 & 0.0169 & 83.8 & 5 & $\mathrm{VE}$ \\
21 & $\mathrm{ML}$ & 16.77 & 0.348 & 0.0282 & 76.8 & 19 & $\mathrm{MR}$ \\
22 & $\mathrm{ML}$ & 4.92 & 1.13 & 0.062 & 57.7 & $\mathrm{NP}$ & $\mathrm{E}$ \\
23 & $\mathrm{SM}$ & 0.14 & 71.87 & 0.1538 & 31.7 & $\mathrm{NP}$ & $\mathrm{VE}$ \\
24 & $\mathrm{ML}$ & 18.32 & 0.268 & 0.0315 & 78.9 & $\mathrm{NP}$ & $\mathrm{MR}-\mathrm{VR}$ \\
25 & $\mathrm{SM}$ & 1.41 & 5.42 & 0.1091 & 36.1 & $\mathrm{NP}$ & $\mathrm{VE}$ \\
26 & $\mathrm{ML}$ & 5.24 & 2.367 & 0.0384 & 74.4 & $\mathrm{NP}$ & $\mathrm{VE}$ \\
27 & $\mathrm{ML}$ & 1.96 & 2.442 & 0.0075 & 91.9 & 18 & $\mathrm{VE}$ \\
28 & $\mathrm{ML}$ & 0.55 & 26.77 & 0.0111 & 98.9 & $\mathrm{NP}$ & $\mathrm{VE}$ \\
29 & $\mathrm{ML}$ & 13.19 & 0.428 & 0.0437 & 69.7 & 16 & MR \\
\hline
\end{tabular}

Note: $\mathrm{VE}=$ Very Erodible, $\mathrm{E}=$ Erodible, $\mathrm{MR}=$ Moderately Resistant, $\mathrm{R}=$ Resistant, $\mathrm{VR}=$ Very Resistant.

\section{DISCUSSION}

The plot of critical shear stress versus erodibility coefficient is shown in Figure 8. To cover the whole spectrum of the test results, the vertical axis is not limited to 10 as suggested by Hanson and Simon (2001) but extended to more than $1000 \mathrm{~cm}^{3} / \mathrm{N}^{-s}$. The LAR riverbanks material spread from Very Erodible (VE) of loose fine grain sediment to Very Resistant (VR) stiff cemented sand (not on the plot). The erodibility coefficient has negative slope relation, to critical shear stress with coefficient of determination, $\mathrm{R} 2=0.68$.

Figures 9 and 10 depict, respectively, the relation of erosion parameter erodibility coefficient and critical shear stress with particle diameter $\left(\mathrm{D}_{50}\right)$. The erodibility coefficient has the positive slope relation with respect to $D_{50}$, in this range of particle diameter with coefficient of determination of 0.54 . The critical shear stress has a negative slope relation with respect to $D_{50}$ in this range of particle diameter with 
coefficient of determination of 0.51 . Figure 11 shows the plot of erodibility coefficient versus percentage of fine materials. The more fine materials content, the more resistant the soil against erosion. The relation is quite good, with coefficient of determination is 0.52. However, the plot of percentage of fine materials against critical shear stress in Figure 12 shown that the relation is not as good as the relation with erodibility coefficient. The value of coefficient of determination is 0.35 . The plasticity index (PI) has no correlation to both erodibility coefficient and critical shear stress as shown in Figures 13 and 14, respectively. The correlation of erosion parameters was done as a single correlation. Probably the analysis using multiple regressions will lead to a better correlation of several variables in determining the erosion parameters.

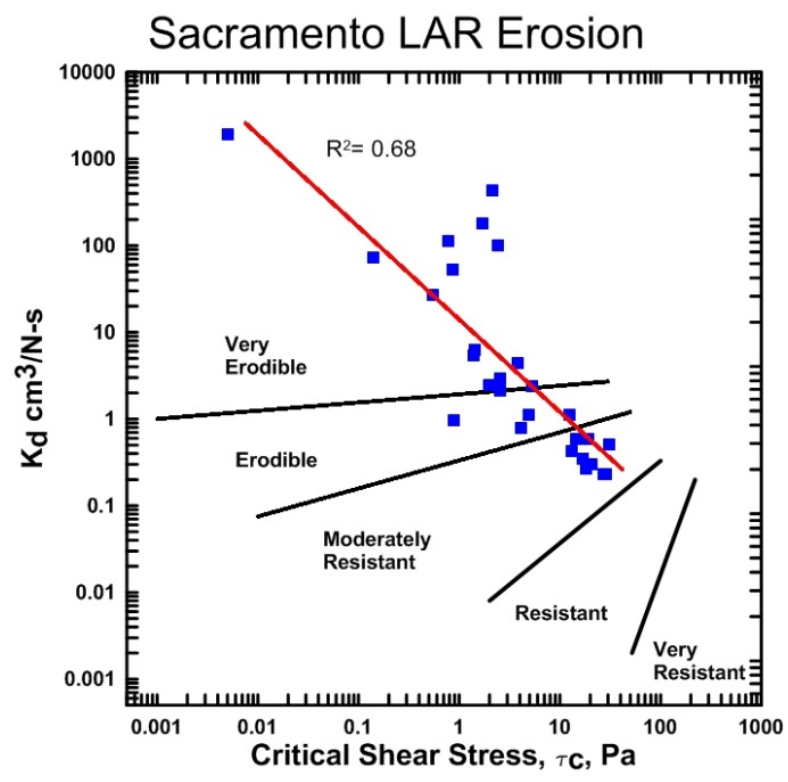

Figure 8. Critical shear stress versus erodibility coefficient of the selected data set.

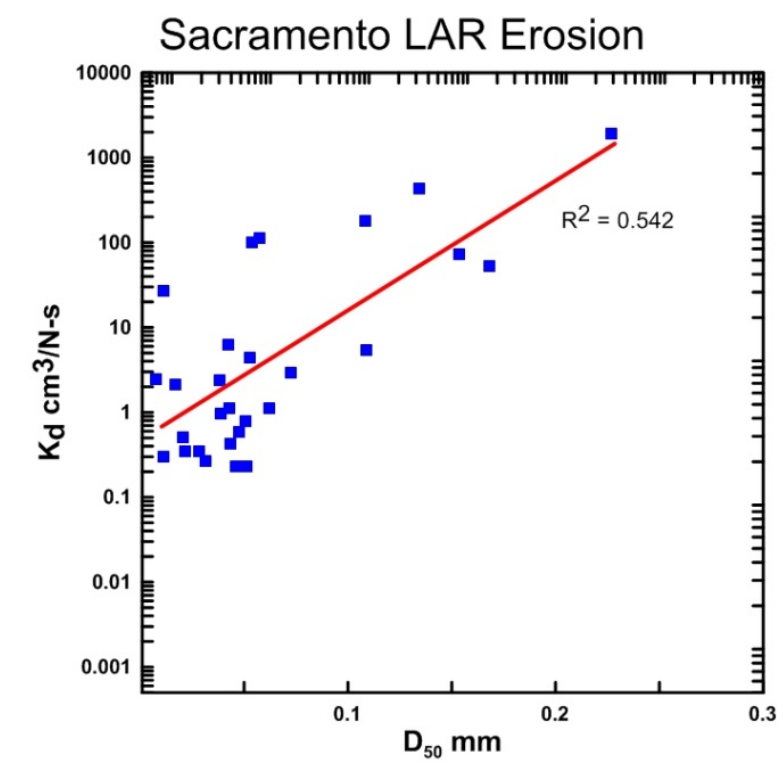

Figure 9. Median particle diameter, $D_{50}$ versus erodibility coefficient of the selected data set.

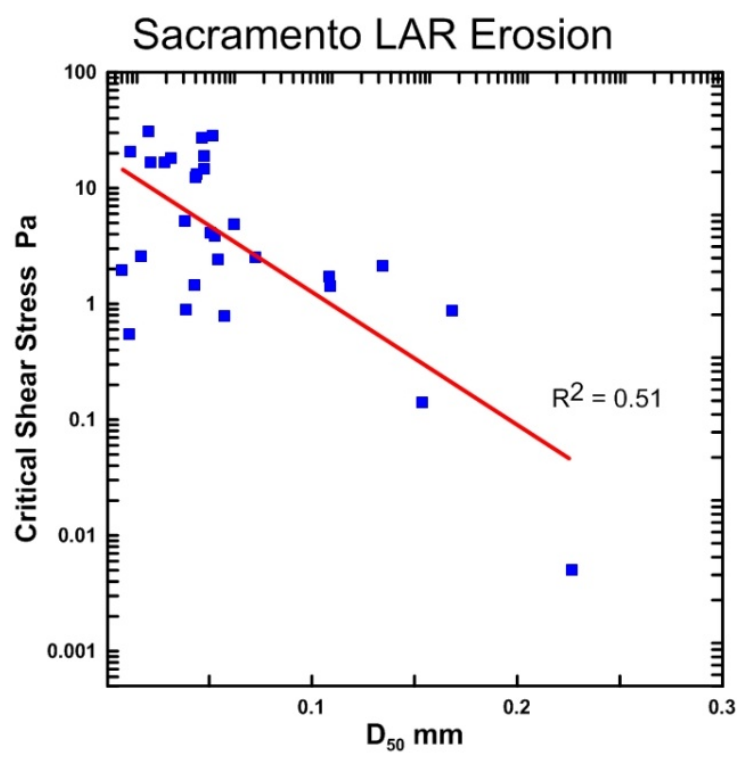

Figure 10. Median particle diameter, $\mathrm{D}_{50}$ versus critical shear stress of the selected data set.

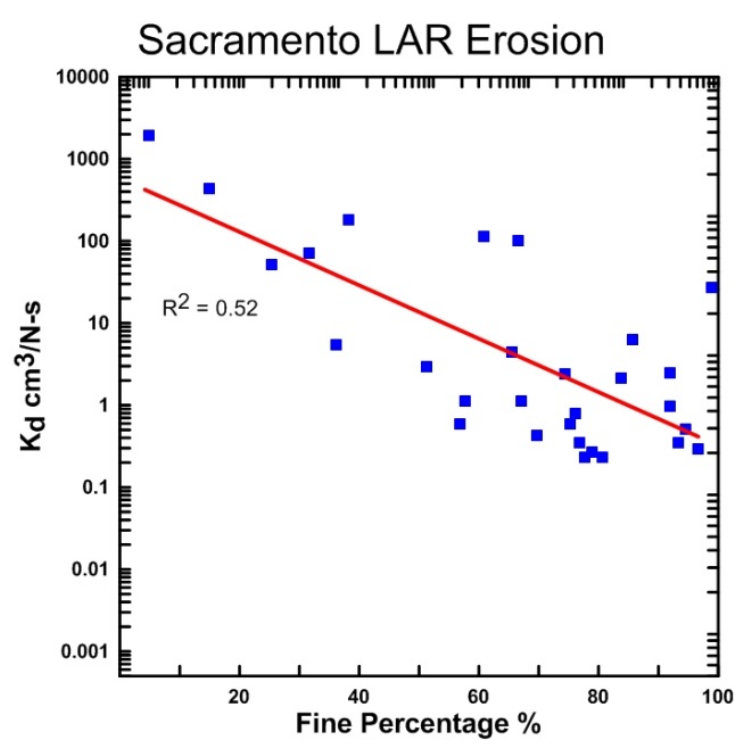

Figure 11. Percentage of fine material versus erodibility coefficient of the selected data set.

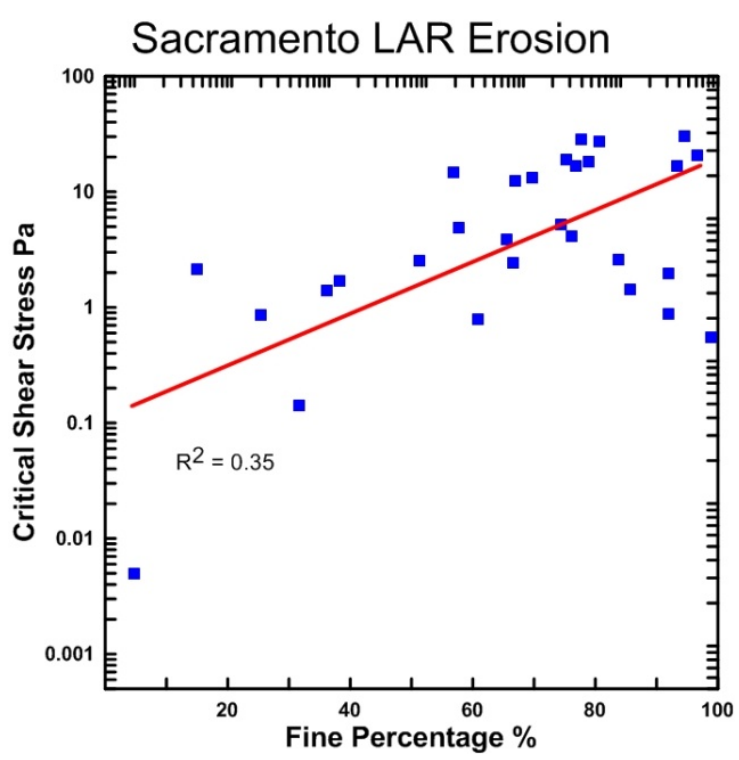

Figure 12. Percentage of fine material versus critical shear stress of the selected data set. 


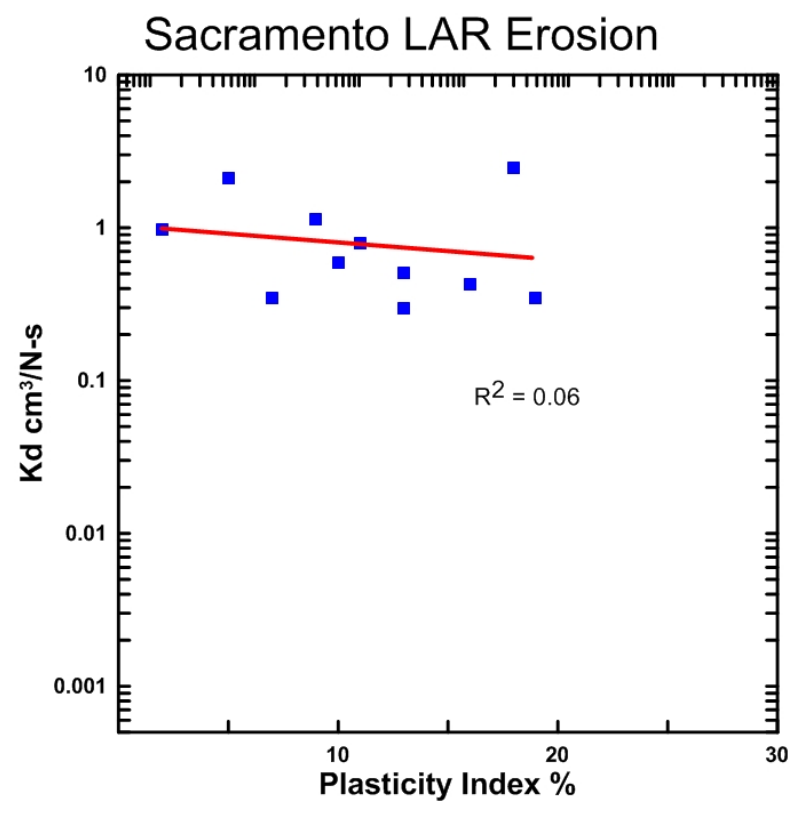

Figure 13. Plasticity Index versus erodibility coefficient of the selected data set.

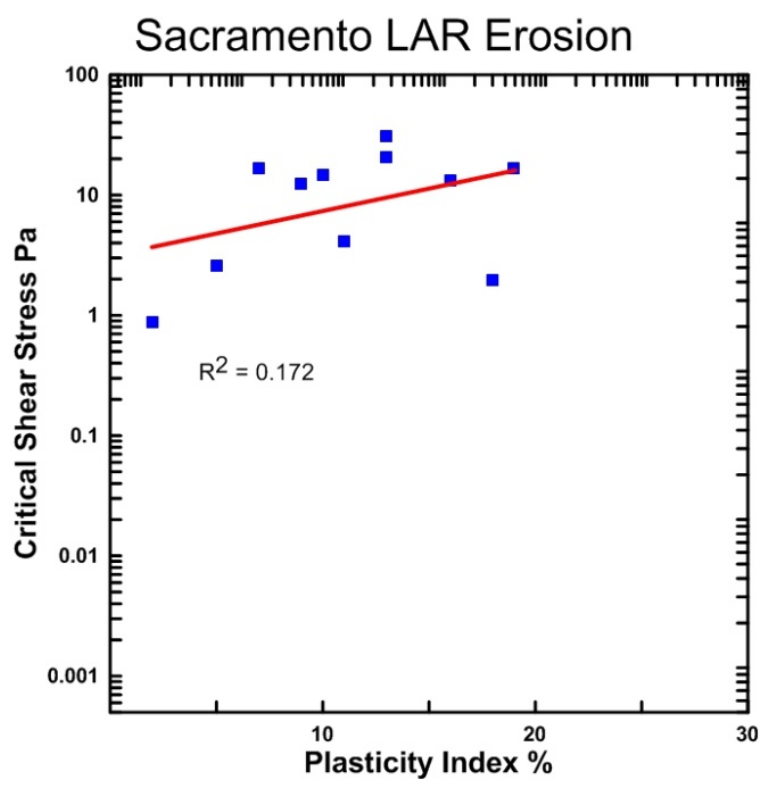

Figure 14. Plasticity Index versus critical shear stress of the selected data set.

\section{CONCLUSIONS}

The erodibility coefficients quite well correlated with critical shear stress with coefficient of determination of 0.68 . The erosion parameters well related to median particle diameter $\mathrm{D}_{50}$ with coefficient of determination of 0.51-0.54. Percentage of fine material related quite well with erodibility coefficient, however not satisfactory relation with critical shear stress. The plasticity has a bad correlation with both, erodibility coefficient and critical shear stress. Probability multi correlation of linear or non-linear regression will give a better coefficient of determination.

\section{ACKNOWLEDGMENTS}

The authors acknowledge and thank the US Army Corp of Engineers, Sacramento District, for the funding and opportunity to perform this study. Specifically, the authors thank Michael Kynett, PE, of the Sacramento District for coordinating this study and the sampling program.

\section{REFERENCES}

ASTM. 2007. Standard test method for erodibility determination of soil in the field or in the laboratory by the Jet Index method. American Society for Testing and Materials Standard Designation D 5852-07, West Conshohocken, PA.

Ayres Associates. 2010. Channel stability analysis of the Lower American River, Folsom Dam to the Confluence. Ayres Associates, Sacramento, CA, p. 92.

Blaisdell, F.W., Anderson, C.L. \& Hebaus, G.G. 1981. Ultimate dimensions of local scour. J. Hydraul. Div., vol. 107 , no. 3, pp. 327-337.

Fairman, D. 2007. A gravel budget for the Lower American River. California State University.

Gilbert, G.K. 1917. Hydraulic-mining debris in the Sierra Nevada. United States Geological Survey, Washington, DC, p. 149.

Hanson, G.J. 1990. Surface erodibility of earthen channels at high stresses: Part II - Developing an in situ testing device. Transactions ASAE, vol. 33, no. 1, pp. 132-137.

Hanson, G.J. 1991. Development of a jet index to characterize erosion resistance of soils in earthen spillways. Transactions ASAE, vol. 34, no. 5, pp. 2015-2020.

Hanson, G.J. \& Cook, K.R. 1997. Development of excess shear stress parameters for circular jet testing. American Society of Agricultural Engineers. St. Joseph, MI.

Hanson, G.J. \& Cook, K.R. 2004. Apparatus, test procedures, and analytical methods to measure soil erodibility in situ. Appl. Eng. Agric., vol. 20, no. 4, pp. 455-462.

Hanson, G.J. \& Simon, A. 2001. Erodibility of cohesive streambeds in the loess area of the midwestern USA. Hydrol. Process., vol. 38, no. Accepted August 1999, pp. 23-38.

Hanson, G.J., Simon, A. \& Cook, K.R. 2002. Non-vertical jet testing of cohesive streambank materials. American Society of Agricultural Engineers Meeting. St. Joseph, MI.

Hanson, G.J., Temple, D.M., Morris, M., Hassan, M. \& Cook, K. 2005. Simplified Breach Analysis Model for Homogeneous Embankment: Part II, Parameter Inputs and Variable Scale Model Comparisons. In USSD Proceedings: Technologies to Enhance Dam Safety and the Environment, pp. 163-174.

James, L.A. 1997. Channel incision on the Lower American River, California, from streamflow gage records. Water Resour. Res., vol. 33, no. 3, pp. 485-490.

Robbins, B.A. \& Wibowo, J.L. 2015. Lessons Learnd from Laboratory Jet Erosion Testing of Undisturbed Samples. ASDSO Conference, September 2015.

Simon, A., Pollen-Bankhead, N. \& Thomas, R.E. 2011. Development and Application of a Deterministic Bank Stability and Toe Erosion Model for Stream Restoration. In Stream Restoration in Dynamic Fluvial Systems, A Simon, S. J. Bennett, and J. M. Castro, Eds. Washington, DC: American Geophysical Union, pp. 453-474. 
Stein, O.R. \& Nett, D.D. 1997. Impinging jet calibration of excess shear sediment detachment parameters. Trans. ASAE, vol. 40, no. 6, pp. 1573-1580.

Temple, D.M., Hanson, G.J., Neilsen, M.L. \& Cook K. 2005. Simplified Breach Analysis Model for Homogeneous Embankments: Part 1, Background and Model Components. In USSD Proceedings: Technologies to Enhance Dam Safety and the Environment, pp. 151-161.

USDA. 1997. Earth Spillway Erosion Model. In Part 628 Dams: National Engineering Handbook, no. August, Washington, DC: United States Department of Agriculture, p. 13.

USFS. 2013. American River. [Online]. Available: http://www.fws.gov/stockton/afrp/ws projects.cfm? code=A MERR. [Accessed: 12-Jun-2014]. 